\title{
Über die praktischen Bedingungen von Forschung zwischen Theorie und Praxis, Wissenschaften und Künsten \\ On the Practical Conditions \\ of Research between Theory and Practice, the Sciences and the Arts
}

Das vorliegende Buch verbindet sehr unterschiedliche Formen der forschenden Auseinandersetzung mit Fragen und Problemen des Relationalen. Viele Beiträge gehen über die theoretische Analyse (und distanzierende Kritik) von Werken, Begriffen, Diskursen etc. hinaus und experimentieren mit verschränkten Reflexionsweisen diverser, auch außerakademischer Praktiken und Institutionen, in die die Beitragenden eingebunden waren und sind. So bewegen sich diese Beiträge zwischen wissenschaftlichen, künstlerischen und aktivistischen Sicht- und Sprechweisen und werfen praktisch die Frage auf: How to relate Theorie und Praxis, Wissenschaften und Künste?

In der Annäherung an diese Frage ist es zunächst wichtig $\mathrm{zu}$ betonen, dass die beiden Frageteile, basierend auf den Polaritäten von Theorie und Praxis einerseits sowie von Wissenschaften und Künsten andererseits, keineswegs deckungsgleich sind. Denn freilich haben sowohl die Wissenschaften als auch die Künste eigene Formen von Theorie und von Praxis. Anstatt sie also allgemein entlang eines falschen Gegensatzes zu kontrastieren, müsste es darum gehen, die besonderen Formen von Theorie und Praxis im Forschungsprozess der Künste wie der Wissenschaften zu bestimmen und die Felder so partikular zueinander in Beziehung zu setzen, wie dies auch in den Beiträgen dieses Bands verschiedentlich beschrieben und vollzogen wird. Die Science and Technology Studies (STS) haben ein handlungsorientiertes Verständnis von Forschung etabliert, dem es weniger um die theoretischen Hypothesen und um die verfertigten Resultate der Wissenschaften geht als vielmehr um die praktischen Bedingungen ihrer Forschungsverläufe. 1 Diese erscheinen hier als tentative Suchbewegungen in diverse Richtungen, für die das zugrunde liegende Nicht-Wissen ebenso entscheidend ist wie intuitive Techniken, mit

1 Ich beziehe mich hier auf pragmatistische Ansätze in der neueren Wissenschaftsgeschichte bzw. -theorie, die vor allem mit den Namen Isabelle Stengers, Bruno Latour und Hans-Jörg Rheinberger verbunden sind und in der Tradition von Thomas Kuhn, Gaston Bachelard und Ludwik Fleck stehen. 
diesem in produktiver Weise umzugehen. Die vielfältigen Experimentalanordnungen, die diese Suchbewegungen strukturieren, wurden durch die STS als verkörperte Theorien kenntlich und kritisierbar gemacht, die alles andere als neutral sind, insofern sie bestimmte Forschungsverläufe möglich und andere unmöglich machen. Umgekehrt besteht das Potenzial von Theorien weniger in der treffenden Analyse bestehender Verhältnisse als vielmehr im imaginativen Entwurf neuer Anordnungen, die die Bedingungen für andere Verhältnisse schaffen. Die Wechselseitigkeit von theoretischer Imagination und experimenteller Praxis ist dabei nicht als abstrakte Entsprechung zu verstehen; sie vollzieht sich als ein relationaler Prozess. ${ }^{2}$

Ebenso wenig wie solche transversalen Forschungsbeziehungen also außerhalb der Zeit stattfinden, hängen sie im luftleeren Raum: Die beschriebenen Wechselverhältnisse von Theorie und Praxis sind nämlich gemeinhin mit Institutionen verbunden, in denen sie statthaben und in die sie sich einschreiben. Deren Funktion liegt darin, die Forschungsprozesse auf Dauer zu stellen sowie die entsprechenden Verfahren erinnerbar und vergleichbar zu machen. Hierin liegt die (im allgemeinsten Sinne) konservative Rolle der Institutionen, welche indes aufs Engste mit ihrer progressiven Rolle verbunden ist. Wie Nora Sternfeld und Bini Adamczak zeigen, ist es gerade die Bewahrung politischer Spannungen und Kämpfe der Geschichte, materiell eingeschrieben in die Bestände und Exponate, die die Institution des Museums zu einem prädestinierten Ort für die Imagination anderer Vergangenheiten und Zukünfte macht. Das Konservative bildet demnach die Voraussetzung für die Emergenz des Neuen, während dieses Neue umgekehrt das Material der institutionellen Erinner- und Vergleichbarkeit bildet. ${ }^{3}$ So organisieren Institutionen die verschränkten Bedingungen des Ererbens und Erfindens von Theorien und experimentellen Praktiken, wie man in Anlehnung an Melanie Sehgal schließen

2 Diese Auslegung der Wechselverhältnisse von Theorie und Praxis, Diskurs und materieller Kultur in der Forschung, die zunächst mit Blick auf die experimentellen Naturwissenschaften formuliert wurde, ist in der Folge auch auf geisteswissenschaftliche sowie künstlerische Forschungszusammenhänge übertragen worden.

3 Diese pragmatistische Sichtweise erlaubt es, auch Kunstinstitutionen einschließlich Kunstuniversitäten in ihrer besonderen Funktionsweise zu erfassen, insofern diese einerseits mit dem Erbe disziplinärer Verfahren und Handwerke betraut sind und andererseits die - im ,ästhetischen Regime' (Jacques Rancière) von den Künsten eingeforderte - Emergenz des Neuen ermöglichen müssen. 
könnte - die prozessualen Kehrseiten des Vergessens und Ausschließens nicht zu vergessen. 4

Nun sind es aber ebendiese Theorien und Praktiken, die einer Institution nicht nur den (der Tendenz nach) permanenten Charakter eines einheitlichen Prozesses des Ererbens und Erfindens verleihen, sondern diesen auch mit dem verbinden, was außerhalb derselben gedacht und getan wird. Durch den ersten Aspekt, die Permanenz, erhält eine Institution ihre endogene Konsistenz, durch den zweiten Aspekt, den der Porosität, erhält sie ihre exogene Relevanz. Folglich wird die Gestaltung der Grenze einer Institution zu einer für sie wesentlichen Bestimmung und den Projekten, die sich auf dieser situieren, kommt eine besondere Brisanz zu, die womöglich mehr über die Funktionsweise der Institution aussagt als das ,Kerngeschäft' im Zentrum. Von besonderem Interesse sind hier also sowohl die Peripherien bestehender Institutionen als auch parainstitutionelle Einrichtungen. Es ist bezeichnend, dass sich viele der disziplinär und methodisch transversalen, kollektiven Forschungsprojekte, die in den genannten Beiträgen reflektiert wurden, an den Rändern von Kunstinstitutionen bewegen. Dies gilt für die Gruppe FORMATIONS unter Beteiligung von Melanie Sehgal, die sich am Berliner Haus der Kulturen der Welt triffit, sowie für das Netzwerk Terra Critica unter Beteiligung von Kathrin Thiele, das seine ReadingRooms im Casco Art Institute in Utrecht durchführt. Und ebenso für die Hamburger Graduiertenkollegs Versammlung \& Teilhabe sowie Performing Citizenship unter Beteiligung von Sibylle Peters respektive von Mirjam Schaub, die der künstlerischen Forschung eine institutionell hybride Organisationsstruktur für Promotionen bereitstellten. ${ }^{5}$ Und weiter mag es auch für jene künstlerisch forschenden Initiativen wie SAVVY Contemporary und World of Matter gelten, die Tom Holert aus wissenspolitischen Gründen gerade nicht als künstlerische Forschung bezeichnen möchte, insofern er diesen Begriff zu sehr den

4 Neben Melanie Sehgals Essay in diesem Band sei hier auf den Workshop verwiesen, den sie mit der Gruppe FORMATIONS im Rahmen des Festivals IMPACT16 im November 2016 im PACT Zollverein, Essen, unter dem Titel „The Practice of Inheritance“ veranstaltet hat. Siehe Website von FORMATIONS, https://www.formations. link/\#workshops (13.11.2019).

5 Das Graduiertenkolleg Versammlung \& Teilhabe lief von 2012 bis 2014 und ihm folgte das Graduiertenkolleg Performing Citizenship, das von 2015 bis 2017 lief. Beide wurden von einer hybriden Struktur sehr unterschiedlicher Institutionen getragen: dem Kindertheater Forschungstheater/FUNDUS THEATER, dem K3 - Zentrum für Choreographie auf Kampnagel, der Hochschule für Angewandte Wissenschaften Hamburg/ Department Design sowie der HafenCity Universität/Studiengang Kultur der Metropole. 
westlichen Ökonomien sowohl der zeitgenössischen Künste als auch der Wissenschaften verpflichtet sieht. Die Grenze von Institutionen ist freilich in beiden Richtungen durchlässig und oft gehen gerade mit den Aspekten dessen, was oben als exogene Relevanz bezeichnet wurde, auch Einflussnahmen und Verpflichtungen einher, die tief in den Forschungsprozess hineinreichen. Wenn man sich nun demgegenüber nicht durch die Abschottung der Grenze entziehen möchte, bleiben, so scheint es mir, vor allem zwei Möglichkeiten: erstens gut zu prüfen, was die Bedingungen jenes Außen sind, mit dem man sich verbindet, und zweitens trotz aller praktischen Offenheit der Suchbewegung theoretische Gewissheit über die Gründe und Zwecke des Forschens zu bewahren. Welche historischen, geopolitischen, ja planetaren Ausmaße und Bedeutungen diese Aspekte annehmen können, lässt sich an Orit Halperns Beschreibung der Design-Experimente Richard Neutras eindrücklich ablesen.

This book combines very different forms of researching engagement with questions and problems of relationality. Many contributions go beyond theoretical analysis (and distancing critique) of works, concepts, discourses, etc., and experiment with entangled modes of reflection on diverse practices and institutions, including nonacademic ones, in which the contributors were and are involved. These contributions thus move between scholarly, artistic, and activist ways of seeing and speaking, and raise the question: how to relate theory and practice, the sciences and the arts? In approaching this question, it is important to emphasize that the two parts of the question - based on the polarities of theory and practice, on the one hand, and of sciences and arts on the other - are by no means congruent. For, of course, both the sciences and the arts have their own forms of theory and practice. Hence, instead of generally contrasting the sciences and the arts according to a false contradiction, one should rather determine the special forms of theory and practice that characterize the research process in both cases, thus relating the two fields to one another in particular terms. The contributions to this volume are examples of how this kind of analysis can be described and carried out. Science and technology studies (STS) have established a pragmatic understanding of research that is less concerned with the theoretical hypotheses and completed results of the sciences than with the practical conditions of their 
research processes. ${ }^{6}$ From this perspective, these appear as tentative movements of exploration aimed in various directions, depending more on a creative approach to non-knowledge than on what one claims or aims to know. Science and technology studies have made it possible to understand and critique the manifold experimental arrangements that structure these movements as embodied theories that are anything but neutral, insofar as they make certain research processes possible and others impossible. Conversely, the potential of theories might be found less in the apt analysis of existing relations than in the imaginative design of new arrangements that create the conditions for other relations. The reciprocity of theoretical imagination and experimental practice is, however, not to be understood as an abstract correspondence; rather it realizes itself as a relational process. ${ }^{7}$

Such research relations between theory and practice thus exist neither outside of time nor in a vacuum. They are connected to institutions in which they take shape, and into which they inscribe themselves. Institutions function here to render permanent the research processes and to make the corresponding procedures memorable and comparable. ${ }^{8}$ This forms the conservative role (in the most general sense) of an institution, which, however, is closely linked to its progressive role: as Nora Sternfeld and Bini Adamczak show, it is precisely the preservation of political tensions and struggles of history, as materially inscribed in the inventories and exhibits of museums, that predestines this institution to be a place for imagining other pasts and other futures. The conservative role of institutions thus constitutes the prerequisite for the emergence of the new, while the new, in turn, constitutes the material of institutional memory and comparability. In this way, institutions organize the entangled

6 I am referring here to pragmatist approaches in the more recent history and theory of science, which are above all associated with the names of Isabelle Stengers, Bruno Latour, and Hans-Jörg Rheinberger and stand in the tradition of Thomas Kuhn, Gaston Bachelard, and Ludwik Fleck.

7 This interpretation of the interrelations between theory and practice, or discourse and material culture in research, which was initially formulated with a view to the experimental natural sciences, has subsequently been transferred to contexts of research in the humanities and arts.

8 This pragmatist perspective also makes it possible to grasp the particular ways in which art institutions function, including art universities, insofar as they are, on the one hand, entrusted with the legacy of disciplinary procedures and crafts and, on the other, must enable the emergence of the new, as is required of art in the 'aesthetic regime' (Jacques Rancière). 
conditions of inheriting and inventing theories and experimental practices, as one can conclude in following Melanie Sehgal - while also not losing sight of the procedural downsides of forgetting and precluding. ${ }^{9}$

However, it is precisely these theories and practices that give an institution not only the (tendentially) permanent character of a unified process of inheritance and invention, but also connect it with what is thought and done outside it. Through the first aspect, permanence, an institution acquires its endogenous consistency; through the second, porosity, it acquires its exogenous relevance. Consequently, the shaping of the boundary of an institution becomes an essential definition for it, and the projects situated on it become particularly explosive, possibly saying more about the functioning of the institution than the "core business" in the center. Of particular interest here are thus both the peripheries of established institutions and parainstitutional formations. It is significant that many of the disciplinary and methodologically transversal collective research projects reflected in the contributions to this book are situated on the margins of art institutions. This applies to the FORMATIONS group with the participation of Melanie Sehgal, which meets at the Haus der Kulturen der Welt in Berlin, as well as to the Terra Critica network with the participation of Kathrin Thiele, which conducts its ReadingRooms at Casco Art Institute in Utrecht. This is also the case for the graduate schools "Assemblies \& Participation" as well as "Performing Citizenship" conducted by, among others, Sibylle Peters and Mirjam Schaub, who thereby created an institutionally hybrid structure for practice-based $\mathrm{PhD}$ projects in the field of artistic research. ${ }^{10}$ And it may also apply to initiatives

9 In addition to Melanie Sehgal's essay in this volume, I refer here to the workshop that she organized with the group FORMATIONS at the IMPACT16 festival in November 2016 at the PACT Zollverein, Essen, under the title "The Practice of Inheritance." Their description: "In this workshop we address the question of inheritance. How do we inherit what precedes us, actively and passively? Every practice explicitly or implicitly positions itself in relation to its past - through its methodologies, its material-discursive set-up, its references." See the announcement text on the FORMATIONS website, https://www.formations.link/\#workshops (last access: November 13, 2019).

10 The graduate school "Assemblies \& Participation" ran from 2012 to 2014 in Hamburg and was followed by "Performing Citizenship," which ran from 2015 to 2017. Both were supported by a hybrid structure of very different institutions: the Children's Theater FUNDUS THEATER/Theatre of Research, the K3-Centre for Choreography at Kampnagel, the University of Applied Sciences Hamburg, Department Design, and the HafenCity University, Department Metropolitan Culture. 
that carry out art-based research, such as Savvy Contemporary and World of Matter - which Tom Holert, for reasons of political epistemology, does not want to identify as artistic research, since he considers this term to be too closely connected with Western economies of both contemporary arts and academia.

The boundary of institutions is, of course, permeable in both directions and often the aspects of what has been described above as exogenous relevance go hand in hand with influences and obligations that reach deep into the research process. Hence, if one does not wish to evade the problem by sealing off the borders of institutions, it seems to me that two possibilities remain: first, to carefully examine those external conditions with which one connects; and second, despite all the practical openness characterizing the exploratory movements, to preserve theoretical certainty about the reasons and purposes of research. The historical, geopolitical, even planetary dimensions and meanings to which these questions might amount can be impressively gleaned from Orit Halpern's description of Richard Neutra's design experiments at the end of this book.

\section{Bini Adamczak und Nora Sternfeld im Gespräch Konvergenz der Zukünfte: Über widerständige Ästhetiken, imaginative Gegengeschichten und Institutionen als Beziehungsweisen}

Nora Sternfeld, Kunst- und Kulturwissenschaftlerin, Kunstvermittlerin, Kuratorin und documenta-Professorin an der Kunsthochschule Kassel, geht in ihren jüngeren Arbeiten der Frage nach, wie die Institution des Museums auf radikaldemokratische Weise (neu) gedacht und praktiziert werden kann, um als ein Ort der Vermittlung zu fungieren, an dem wir etwas „voneinander lernen können, das es noch nicht gibt". ${ }^{1}$ Bini Adamczak, Theoretikerin und Künstlerin in Berlin, erforscht politische Handlungszusammenhänge und hat mit ihrem letzten Buch, Beziehungsweise Revolution. 1917, 1968 und 